\title{
Agronomical Performances of Angolan Natural Oil Palm Accessions and Interests for Oil Palm Selection in Côte d'Ivoire
}

\author{
Benjamin Adon ${ }^{1}$, Jean Noel Konan ${ }^{1}$, Benoît Cochard ${ }^{2}$, Albert Flori ${ }^{2}$, Sekou Diabaté ${ }^{1}$, Claude Bakoumé \\ $\&$ Didier Paulin Sokouri ${ }^{4}$ \\ ${ }^{1}$ CNRA Station Principale de La Mé, Abidjan, Côte d'Ivoire \\ ${ }^{2}$ CIRAD-CP, Montpellier, France \\ ${ }^{3}$ Maxi Productivity Sarl, Douala, Cameroon \\ ${ }^{4}$ Université Felix Houphouet-Boigny, Abidjan, Côte d'Ivoire \\ Correspondence: Benjamin Adon, CNRA Station Principale de La Mé 13 B.P. 989 Abidjan 13, Côte d'Ivoire. Tel: \\ 225-0734-8099/0861-8230. E-mail: benjamin_adon@yahoo.fr
}

Received: July 30, $2021 \quad$ Accepted: September 1, $2021 \quad$ Online Published: October 15, 2021

doi:10.5539/jas.v13n11p64 URL: https://doi.org/10.5539/jas.v13n11p64

\begin{abstract}
In Côte d'Ivoire, Deli populations, descendants of four oil palms, constituted Group A of the recurrent reciprocal selection. Their genetic base was narrow, an obstacle to long-term genetic progress. Therefore, Angolan oil palm accessions were acquired to broaden Group A's genetic base. Angola selfed and Deli $\times$ Angola progenies were tested via Angola selfed $\times$ La Mé and (Deli $\times$ Angola) $\times$ La Mé intergroup hybrids for bunch and oil production, height growth, and tolerance to Fusarium in two progeny trials; one in La Mé (Côte d'Ivoire) and the other one in Bangun Bandar (Indonesia). On average, bunch yield (183 kg/palm/year) and oil yield (5.34 t/ha) were close to those of the control. The best 5 hybrids represented 104-112\% of the control all traits put together. In addition, Angolan origin has transmitted tolerance to Fusarium to its progenies (Fusarium index $=80-90)$. [(Deli $\times$ Angola)'s LM $5448 \mathrm{~T}$ ] $\times$ La Mé hybrids yielded $241.4 \mathrm{~kg} / \mathrm{palm} /$ year of bunch and $7.30 \mathrm{t} / \mathrm{ha}$ of palm oil. Their mean height was comparable to that of the control and the Fusarium index low (82). Therefore, LM 5448 T was selected for further crop improvements. The modalities of its use were proposed.
\end{abstract}

Keywords: bunch production, genetic evaluation, genetic resources, oil palm, oil yield, Côte d'Ivoire

\section{Introduction}

Plant genetic resources, including those of oil palm, are a vital component of plant breeding without which plant improvement is impossible (Acquaah, 2007). At the oil palm research station of La Mé (Côte d'Ivoire), the improvement of productivity and other agronomic characteristics of oil palm uses the recurrent reciprocal selection scheme (RRS) (Meunier \& Gascon, 1972). RRS exploits the complementarity of two groups A and B of oil palms: group A made up of oil palm populations with a small number of large bunches and group B of oil palm populations with a large number of small bunches.

Group B assembles a considerable number of palms from different African origins including La Mé (Côte d'Ivoire), Pobè (Benin), Lobé and Widikum (Cameroon), Yangambi (DR Congo), Sibiti (Congo), Calabar and Cowan (Nigeria) to name but a few. Group A is solely comprised of Deli provenance. It consists of dura type palms descended from four dura oil palms introduced into the Botanical Garden of Bogor (Indonesia) in 1848 (Hartley, 1977). The Deli dura used in oil palm breeding at La Mé are descendants of the third and fourth generations of selection.. The resulting populations are considered to have a narrow genetic base (Rosenquist, 1990). In fact, the frequency of genes related to traits of interest to the industry (bunch production) has been increased to the detriment of that of traits not directly related to production. However, the long-term effectiveness of a genetic improvement programme depends on the wide variability of available genetic resources (Gallais, 1990). Therefore, introductions of oil palm materials from new sources, including accessions from sub-spontaneous palm groves, are undertaken before each new selection cycle (Adon et al., 1993, Adon et al., 1998, Bakoume et al., 2001). It is in this context that Angolan natural oil palm accessions from the localities of Salazar and Novo Redondo Nhime were introduced in the Oil Palm Research Station of La Mé (Côte d'Ivoire) in 1971. A first stage of evaluation of the said palms was carried out by crossing them with genitors from Deli 
(Asia), La Mé (Côte d'Ivoire), Yangambi (Democratic Republic of Congo) and by crossing them with each other as well. In the latter case, Angola $\times$ Angola populations were created (Adon, 1995, Adon et al., 1998). The first evaluation led to selecting Angolan genitors. Unfortunately, their mean total fresh bunch weight, average bunch weight, fruit to bunch ratio, and mesocarp to fruit ratio did not allow them to be directly introduced into the general oil palm improvement scheme despite their good tolerance to Fusarium wilt.

The present study that corresponds to the second stage of evaluation of Angola's oil palm materials, seeks to improve the frequency and the stability of characters of agronomic interest through selfing of candidate Angola genitors and combinations with well renowned Deli Dabou dura. Progeny trials were planted at La Mé (Côte d'Ivoire) in 1985 and Bangun Bandar (Indonesia) in 1986. The aim was to select Angola or Angola $\times$ Deli genitors with good general combining ability for bunch production, oil production, low height growth, and tolerance to Fusarium oxysporum elaeidis. In fact, the economic life of an oil palm plantation depends on the height growth rate. Slow growing oil palms have a long economic life. Fusarium oxysporum elaeidis is a causal agent of a fungal disease of the same name Fusarium which is endemic to African palm groves. Selected genotypes will be integrated into Group A to enrich it and increase its genetic variability.

\section{Materials and Methods}

\subsection{Planting Material}

Progenies evaluated were hybrids resulting from crosses between Deli $\times$ Angola or Angola selfed (Group A) and La Mé selfed and La Mé $\times$ La Mé partners (Group B). A total of 17 genitors of Deli $\times$ Angola or Angola selfed origin and 2 Deli dura (LM 5489 D, LM 5885 D) genitors (forming group A) were tested with 13 partners from La Mé selfs and 8 La Mé $\times$ La Mé intra-origin crosses within Group B. The ancestries of La Mé genitors and Angola-derived parents are shown in Figures 1 and 2.

\section{BINGERVILLE}

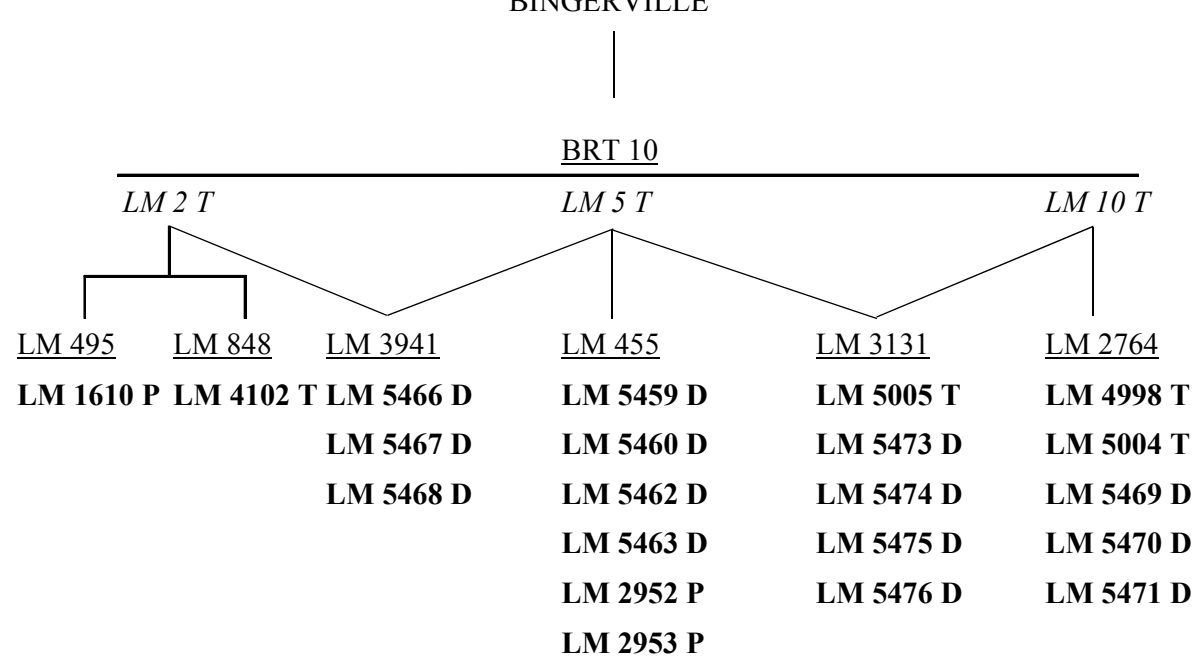

Figure 1. Genealogy of La Mé genitors

Note. Progenies are underlined. Genitors of first selection cycle are in italics. Genitors of the second cycle of selection tested are in bold. 


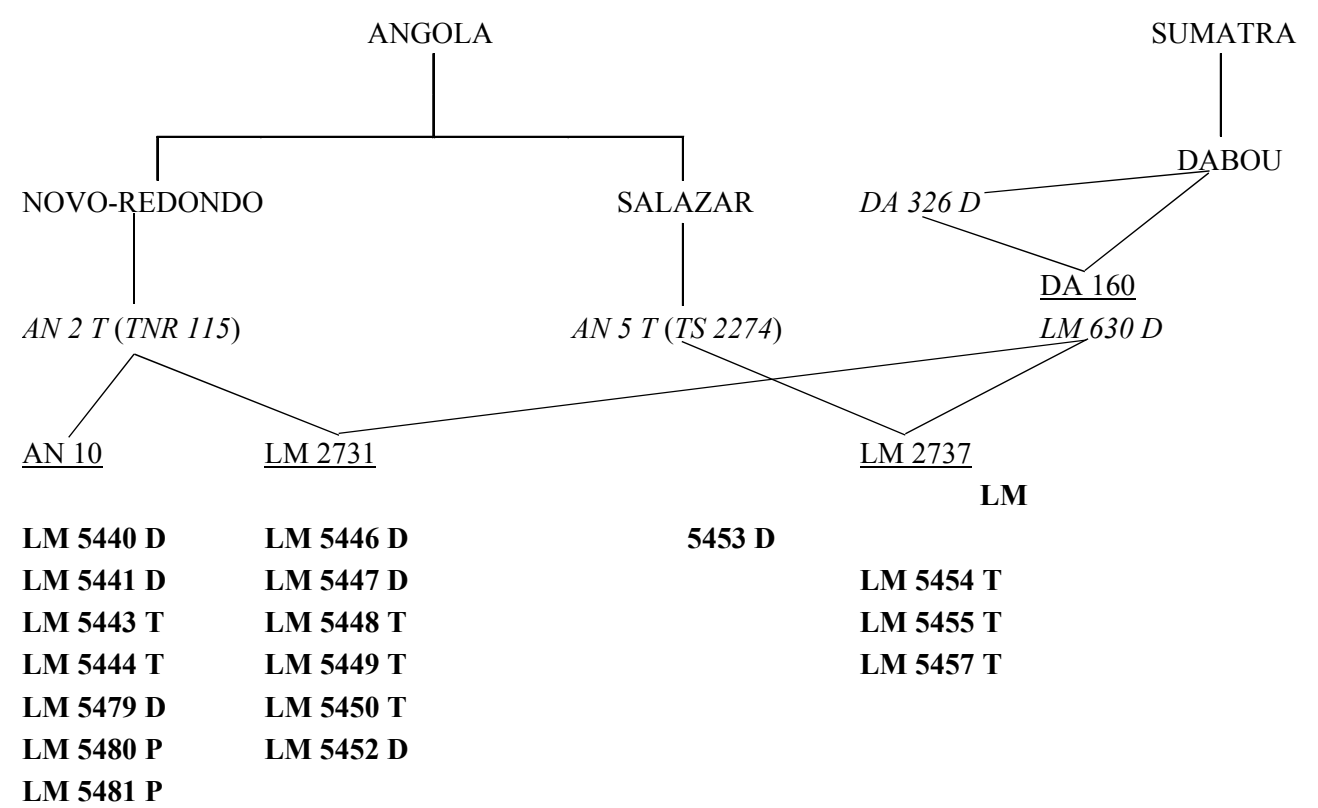

Figure 2. Ancestry of Angola-derived genitors of the second cycle of selection

Note. Progenies are underlined. Genitors of first selection cycle are in italics. Genitors of the second cycle of selection tested are in bold.

A total of 35 progenies were field tested in La Mé (24 progenies) and Bangun Bandar (12 progenies). Four progenies were common to the two trials notably the control (LM $2 \mathrm{~T} \times \mathrm{DA} 10 \mathrm{D})$ and progenies LM 11720, LM 12231, and LM 12281 derived from Angola $\times$ La Mé or (Angola $\times$ Deli) $\times$ La Mé crosses. The control cross (LM $2 \mathrm{~T} \times \mathrm{DA} 10 \mathrm{D}$ )-derived progeny was labelled LM 11380 and LM 12649 in the La Mé trial and Bangun Bandar trial, respectively. In fact, the progeny from LM $2 \mathrm{~T} \times \mathrm{DA} 10 \mathrm{D}$ cross was one of the best progenies of the first selection cycle. The second selection cycle used it as a control) (Table 1). The four common progenies subsequently served as a bridge (or link) between the two trials. The La Mé (Côte d'Ivoire) trial was laid in 1985 whereas the Bangun Bandar (Indonesia) progeny trial was established in 1986. La Mé oil palm research station is located in the retreat of the Gulf of Guinea, at $5^{\circ} 26^{\prime} \mathrm{N}$ latitude and $3^{\circ} 50^{\prime}$ west longitude (Quencez, 1996). It is within an ombrophilic sector and benefits from a transitional tropical climate. The rainfall is abundant, very unevenly distributed throughout the year, and in decreasing trend with an average of $1740 \mathrm{~mm} /$ year (Quencez, 1996). The average annual water deficit is about $350 \mathrm{~mm}$. The soil was formed on ferrallitic tertiary sediments and was considered poor in organic matter (Ollagnier et al., 1978). The average sunshine is $1,800 \mathrm{~h} /$ year. The Bangun Bandar oil palm research station is situated on volcanic soil (Tampubolo et al., 1990). Rainfall is abundant and well distributed throughout the year. Hence, there is no water deficit and the palm trees benefit from a shallow water table. Sunshine is more than $2,000 \mathrm{~h} /$ year. The experimental design was a Fisher block with 6 replicates and 12 palm trees per elementary plot, i.e., 72 trees per progeny. The planting density was 143 palm trees per hectare. 
Table 1. Crosses of provenance of hybrid progenies tested in trials LM GP56 and BB GT25

\begin{tabular}{|c|c|c|}
\hline Progeny & Cross type & Progeny serial number in the trial \\
\hline \multicolumn{3}{|c|}{ Trial LM GP 56} \\
\hline \multicolumn{3}{|c|}{ Control: La Mé × Deli } \\
\hline LM 11380 & $\mathrm{LM} 2 \mathrm{~T} \times \mathrm{DA} 10 \mathrm{D}$ & 1 \\
\hline \multicolumn{3}{|c|}{$($ Deli $\times$ Angola Novo-Redondo) $\times$ La Mé } \\
\hline \multicolumn{3}{|c|}{$($ LM $630 \mathrm{D} \times$ TNR 115$) \times$ La Mé } \\
\hline LM 11622 & LM $5447 \mathrm{D} \times \mathrm{LM} 5005 \mathrm{~T}$ & 2 \\
\hline LM 11413 & LM $5460 \mathrm{D} \times \mathrm{LM} 5449 \mathrm{~T}$ & 3 \\
\hline LM 11407 & LM $5468 \mathrm{D} \times$ LM $5449 \mathrm{~T}$ & 4 \\
\hline LM 11603 & LM $5470 \mathrm{D} \times \mathrm{LM} 5450 \mathrm{~T}$ & 5 \\
\hline LM 11772 & LM $5446 \mathrm{D} \times \mathrm{LM} 4102 \mathrm{~T}$ & 6 \\
\hline \multicolumn{3}{|c|}{ (Deli $\times$ Angola Salazar) $\times$ La Mé } \\
\hline \multicolumn{3}{|c|}{$(\mathrm{LM} 630 \mathrm{D} \times \mathrm{TS} 2274) \times$ La Mé } \\
\hline LM 12231 & LM $5453 \mathrm{D} \times \mathrm{LM} 4998 \mathrm{~T}$ & 7 \\
\hline LM 11503 & LM $5462 \mathrm{D} \times \mathrm{LM} 5455 \mathrm{~T}$ & 8 \\
\hline LM 11725 & LM $5471 \mathrm{D} \times \mathrm{LM} 5455 \mathrm{~T}$ & 9 \\
\hline LM 11720 & LM $5457 \mathrm{~T} \times \mathrm{LM} 5459 \mathrm{D}$ & 10 \\
\hline \multicolumn{3}{|c|}{ Angola Novo-Redondo selfed $\times$ La Mé } \\
\hline \multicolumn{3}{|c|}{ TNR 115 selfed $\times$ La Mé } \\
\hline LM 11839 & LM 5440 D $\times$ LM 2953 P & 11 \\
\hline LM 11353 & LM $5441 \mathrm{D} \times \mathrm{LM} 1610 \mathrm{P}$ & 12 \\
\hline LM 11821 & LM 5441D × LM 2952 P & 13 \\
\hline LM 11494 & LM $5441 \mathrm{D} \times \mathrm{LM} 5004 \mathrm{~T}$ & 14 \\
\hline LM 12281 & LM $5443 \mathrm{~T} \times$ LM $5467 \mathrm{D}$ & 15 \\
\hline LM 11856 & LM $5443 \mathrm{~T} \times$ LM $5475 \mathrm{D}$ & 16 \\
\hline LM 11964 & LM $5463 \mathrm{D} \times \mathrm{LM} 5444 \mathrm{~T}$ & 17 \\
\hline LM 11749 & LM $5444 \mathrm{~T} \times$ LM $5466 \mathrm{D}$ & 18 \\
\hline LM 11319 & LM $5473 \mathrm{D} \times \mathrm{LM} 5444 \mathrm{~T}$ & 19 \\
\hline LM 11548 & LM $5470 \mathrm{D} \times \mathrm{LM} 5479 \mathrm{D}$ & 20 \\
\hline LM 11225 & LM 5474 D $\times$ LM 5479 D & 21 \\
\hline LM 11623 & LM $5471 \mathrm{D} \times \mathrm{LM} 5480 \mathrm{P}$ & 22 \\
\hline LM 11442 & LM 5476 D $\times$ LM 5480 P & 23 \\
\hline LM 11633 & LM $5469 \mathrm{D} \times$ LM $5481 \mathrm{P}$ & 24 \\
\hline \multicolumn{3}{|c|}{ Trial BB GT25 } \\
\hline \multicolumn{3}{|c|}{ Control: La Mé $\times$ Deli } \\
\hline LM 12649 & $\mathrm{LM} 2 \mathrm{~T} \times \mathrm{DA} 10 \mathrm{D}$ & 1 \\
\hline \multirow{2}{*}{\multicolumn{3}{|c|}{$\begin{array}{l}(\text { Deli } \times \text { Angola Novo-Redondo }) \times \text { La Mé } \\
(\text { LM } 630 \mathrm{D} \times \mathrm{TNR} 115) \times \text { La Mé }\end{array}$}} \\
\hline & & \\
\hline LM 12283 & LM $5448 \mathrm{~T} \times \mathrm{LM} 5463 \mathrm{D}$ & 2 \\
\hline LM 12273 & LM $5467 \mathrm{D} \times \mathrm{LM} 5448 \mathrm{~T}$ & 3 \\
\hline LM 12293 & LM $5476 \mathrm{D} \times \mathrm{LM} 5448 \mathrm{~T}$ & 4 \\
\hline LM 12433 & LM $5452 \mathrm{D} \times \mathrm{LM} 5335 \mathrm{P}$ & 5 \\
\hline \multicolumn{3}{|c|}{$($ Deli $\times$ Angola Salazar) $\times$ La Mé } \\
\hline \multicolumn{3}{|c|}{$(\mathrm{LM} 630 \mathrm{D} \times \mathrm{TS} 2274) \times$ La Mé } \\
\hline LM 12231 & LM $5453 \mathrm{D} \times \mathrm{LM} 4998 \mathrm{~T}$ & 6 \\
\hline LM 11406 & LM $5473 \mathrm{D} \times \mathrm{LM} 5454 \mathrm{~T}$ & 7 \\
\hline LM 11720 & LM $5457 \mathrm{~T} \times \mathrm{LM} 5459 \mathrm{D}$ & 8 \\
\hline LM 11337 & LM $5468 \mathrm{D} \times \mathrm{LM} 5454 \mathrm{~T}$ & 9 \\
\hline \multicolumn{3}{|c|}{ Angola Novo-Redondo selfed $\times$ La Mé } \\
\hline \multicolumn{3}{|c|}{ TNR 115 selfed $\times$ La Mé } \\
\hline LM 12281 & LM $5443 \mathrm{~T} \times$ LM $5467 \mathrm{D}$ & 10 \\
\hline LM 12334 & LM $5469 \mathrm{D} \times \mathrm{LM} 5445 \mathrm{~T}$ & 11 \\
\hline LM 11440 & LM $5440 \mathrm{D} \times \mathrm{LM} 2042 \mathrm{~T}$ & 12 \\
\hline
\end{tabular}

Note. LM GP 56: La Mé's $56^{\text {th }}$ genetic trial; LM: La Mé; T: tenera; DA: Dabou; D: dura; P: pisifera; BB GT25: Bangun Bandar's $25^{\text {th }}$ genetic trial. 


\subsection{Parameters Measured}

Bunch production was recorded for each palm for seven years from 3 years after planting. The period 3-6 years after planting was the juvenile period and the period 9-10 years the adulthood.

The characteristics of the bunch and the fruit were determined by carrying out 2 series of physico-chemical analyses of bunches, at 5 and 6 years of age, on a sample of 30 to 40 bunches harvested from tenera palms from each progeny. Analyses led to determining (i) percentage of fruit per bunch (F/B), (ii) percentage of pulp (or mesocarp) per fruit $(\mathrm{P} / \mathrm{F})$, (iii) oil to pulp ratio $(\mathrm{O} / \mathrm{P})$, and (iv) palm oil extraction rate (OER). OER has been deducted from $\mathrm{F} / \mathrm{B}, \mathrm{P} / \mathrm{F}$ and $\mathrm{O} / \mathrm{P}$ using the following arithmetic formula:

$$
\mathrm{OER}=\mathrm{F} / \mathrm{B} \times \mathrm{P} / \mathrm{F} \times \mathrm{O} / \mathrm{P} \times 0.855
$$

Where, 0.855 is a coefficient that takes into account the various losses during the extraction of palm oil from the fresh fruit bunch.

Palm tree height was measured at 6 and 9 years of age according to the method described by Jacquemard (1979). It corresponded to the distance between the soil surface and the axil of the leaf 33 , which generally bears a ripe and harvestable fresh fruit bunch or a rotten male inflorescence. Data recorded were used in the estimates of the vertical growth rate.

Progenies were tested for tolerance (or resistance) to Fusarium according to the method described by Renard et al. (1972). The Fusarium index (FI) of a progeny was the ratio of the number of Fusarium-infected individuals in the progeny to the average number of plants attacked in the test multiplied by 100 . The Fusarium index 100 was attributed to the mean number of Fusarium-infected palms in the test. Any value lower than the index corresponds to a more tolerant (or resistant) progeny.

\subsection{Data Analysis}

An analysis of variance was carried out for total bunch weight, oil yield, and height growth for the periods of 3-6 years and 9-10 years after planting. Emphasis was put on progeny effect and progeny $\times$ station interaction. The analysis of variance model used was as follows:

$$
\mu=\mathrm{m}+\mathrm{D}+\mathrm{S}
$$

where, $\mu$ is the mean of the station progeny, $\mathrm{m}$ is the overall mean, $\mathrm{D}$ is the downfall effect, $\mathrm{S}$ is the station effect.

An analysis of variance was also carried out for total bunch weight, oil yield and height growth for the periods of 3-6 years and 9-10 years after planting in a search of Angolan origin, La Mé origin and Angolan genitors effects. The statistical model used was as follows:

$$
\mu=m+\text { Origin La Mé }+ \text { Parent Angola }+ \text { Origin Angola }
$$

where, $\mu$ is the progeny mean, $m$ is the overall mean, La Mé origin is La Mé origin effect, Parent Angola is the Angola parent effect, origin Angola is the Angola origin effect.

The comparison of mean values of the different progenies for each of the parameters measured was carried out using Tukey's test However, only mean values of height of progenies from the genetic trial planted in La Mé (Côte d'Ivoire) whose heights were measured were compared.

\section{Results}

\subsection{Progeny Effect and Progeny $\times$ Station Interaction}

The analysis of variance detected a highly significant difference between the progenies tested, for bunch production and its components at 3-6 years after planting as well as at 9-10 years' period, and oil yield. Difference was also found for tree height between 6 and 9 years. On the other hand, the analysis detected an absence of progeny $\times$ station interaction (Table 2). In the absence of progeny $\times$ station interaction, means were adjusted for each of the progenies studied for the components of bunch production and oil yield, over the periods of 3-6 years and 9-10 years after planting. 
Table 2. Analysis of variance for bunch production and its components and height

\begin{tabular}{|c|c|c|c|c|c|c|c|c|}
\hline & NR 3-6 years & TBW 3-6 years & ABW 3-6 years & NR 9-10 years & TBW 9-10 years & ABW 9-10 years & GR 6-9 years & Oil yield \\
\hline Station & $58.6 * *$ & $69.21 * *$ & $\mathrm{O} .4 \mathrm{O} \mathrm{ns}$ & $2.23 \mathrm{~ns}$ & $10.98 * *$ & $9.43 *$ & $55.5 * *$ & $6.99 *$ \\
\hline Progeny & $8.14 * *$ & $2.42 * *$ & $18.5 * *$ & $5.30 * *$ & $1.59 *$ & $10.45 * *$ & $7.35 * *$ & $4.65 * *$ \\
\hline Station $\times$ Progeny & $0.89 \mathrm{~ns}$ & $1.21 \mathrm{~ns}$ & $1.07 \mathrm{~ns}$ & $0.49 \mathrm{~ns}$ & $1.19 \mathrm{~ns}$ & $0.61 \mathrm{~ns}$ & $-2.09 \mathrm{~ns}$ & \\
\hline
\end{tabular}

Note. BN: bunch number; TBW: total bunch weight; ABW: average bunch weight; GR: height growth rate.

\subsection{Effects Angola Origin, La Mé Origin, and Angola Parents}

No difference was observed between La Mé origin (selfs and crosses), Angola origin (Angola selfed and Angola $\times$ Deli combinations) and Angola parents as well, for all the variables studied viz BN, TBW, and ABW at 3-6 years and 9-10 years and vertical growth rate at 9 years after planting (Table 3 ).

Table 3. Analysis of variance of origins and Angola parent for bunch production and its components and height

\begin{tabular}{llllllll}
\hline Source of variation & NR 3-6 years & TBW 3-6 years & ABW 3-6 years & NR 9-10 years & TBW 9-10 years & ABW 9-10 years & GR \\
\hline La Mé Origin & $0.74 \mathrm{~ns}$ & $1.61 \mathrm{~ns}$ & $2.27 \mathrm{~ns}$ & $0.00 \mathrm{~ns}$ & $0.44 \mathrm{~ns}$ & $0.42 \mathrm{~ns}$ & $11.07 \mathrm{~ns}$ \\
Angola Parent & $4.36 \mathrm{~ns}$ & $1.28 \mathrm{~ns}$ & $20.30 \mathrm{~ns}$ & $1.28 \mathrm{~ns}$ & $0.83 \mathrm{~ns}$ & $2.53 \mathrm{~ns}$ & 8.51 \\
Angola Origin & $0.59 \mathrm{~ns}$ & $1.49 \mathrm{~ns}$ & $6.35 \mathrm{~ns}$ & $0.19 \mathrm{~ns}$ & $1.02 \mathrm{~ns}$ & $0.67 \mathrm{~ns}$ & 5.08 \\
\hline
\end{tabular}

Note. BN: bunch number; TBW: total bunch weight; ABW: average bunch weight; GR: height growth rate.

\subsection{Mean Values of Hybrids Tested}

On average, hybrids tested produced $130 \mathrm{~kg} / \mathrm{tree}(17 \mathrm{t} / \mathrm{ha} / \mathrm{year})$ of fresh fruit bunches at 3-6 years of age and 190 $\mathrm{kg} /$ tree $(26 \mathrm{t} / \mathrm{ha} /$ year) at 9-10 years after planting. The fresh fruit bunches production of the different types of hybrids tested was comparable to that of the control (LM $2 \mathrm{~T} \times \mathrm{DA} 10 \mathrm{D})$ (Table 4). The number of bunches and average bunch weight were also comparable to that of the control. Within each of the hybrids (LM $630 \mathrm{D} \times \mathrm{TNR}$ $115) \times$ La Mé, $($ LM $630 \mathrm{D} \times$ TS 2274) $\times$ La Mé, and TNR $115 \mathrm{AF} \times$ La Mé the variability was moderate for the bunch number (8-12\%) and average bunch weight (5-15\%) and relatively low for total bunch weight of (4-6\%).

Table 4. Mean values of bunch production and its components at young age and maturity of different types of hybrids tested

\begin{tabular}{|c|c|c|c|c|c|c|}
\hline & \multicolumn{6}{|c|}{ Types of hybrids tested } \\
\hline & \multicolumn{2}{|c|}{$($ LM $630 \mathrm{D} \times$ TNR 115$) \times$ La Mé $(8)$} & \multicolumn{2}{|c|}{$($ LM 630 D × TS 2274) × La Mé (7) } & \multicolumn{2}{|c|}{ TNR 115 AF $\times$ La Mé (16) } \\
\hline & Mean & $\mathrm{CV}$ & Mean & $\mathrm{CV}$ & Mean & $\mathrm{CV}$ \\
\hline BN (3-6 years) & 23.4 & $10 \%$ & 23.5 & $4 \%$ & 23.1 & $7 \%$ \\
\hline TBW (3-6 years)* & 128 & $6 \%$ & 126 & $5 \%$ & 128 & $5 \%$ \\
\hline ABW (3-6 years)* & 5.6 & $9 \%$ & 5.3 & $5 \%$ & 5.7 & $15 \%$ \\
\hline $\mathrm{BN}$ (9-10 years) & 14.7 & $12 \%$ & 14.8 & $8 \%$ & 14.5 & $10 \%$ \\
\hline TBW (9-10 years)* & 191 & $6 \%$ & 187 & $4 \%$ & 183 & $6 \%$ \\
\hline ABW (9-10 years)* & 13.5 & $11 \%$ & 13.1 & $8 \%$ & 13.0 & 10 \\
\hline
\end{tabular}

Note. ( ): number of hybrids' progenies; BN: bunch number; TBW: total bunch weight; ABW: average bunch weight; *: mean expressed in $\mathrm{kg} / \mathrm{year}$.

Oil extraction rates (OER) ranged from 20.8 for hybrids (LM $630 \mathrm{D} \times \mathrm{TS} 2274) \times$ La Mé to $21.9 \%$ for hybrids $($ LM $630 \mathrm{D} \times \mathrm{TNR} 115) \times$ La Mé (Table 5). Extraction rates were comparable to that recorded for the control (20.5\%). CV value, an indication of the variability existing within each of these different types of hybrids, ranged from $5 \%$ to $7 \%$. 
Table 5. Mean values of oil extraction rates and oil yields of the different types of hybrids tested at young and mature periods

\begin{tabular}{|c|c|c|c|c|c|c|}
\hline & \multicolumn{6}{|c|}{ Types of hybrids tested } \\
\hline & \multicolumn{2}{|c|}{$($ LM 630 D $\times$ TNR 115) × La Mé $(8)$} & \multicolumn{2}{|c|}{$($ LM 630 D × TS 2274) × La Mé (7) } & \multicolumn{2}{|c|}{ TNR 115 AF $\times$ La Mé (13) } \\
\hline & Mean & $\mathrm{CV}$ & Mean & $\mathrm{CV}$ & Mean & $\mathrm{CV}$ \\
\hline OER * & 21.9 & $7 \%$ & 20.8 & $7 \%$ & 20.8 & $5 \%$ \\
\hline Oil (3-6 years)** & 3.78 & $10 \%$ & 3.50 & $9 \%$ & 3.57 & $5 \%$ \\
\hline Oil (9-10 years) $* *$ & 5.64 & $10 \%$ & 5.26 & $9 \%$ & 5.13 & $7 \%$ \\
\hline
\end{tabular}

Note. OER: oil extraction rate; ( ): number of hybrids' progenies; CV: coefficient of variation; *: mean expressed in $\%$; **: mean given $\mathrm{t} / \mathrm{ha} /$ year.

Hybrids' oil yields at 3-6 years and 9-10 years were close to those of the control cross (Table 5). The variability in the hybrids (LM $630 \mathrm{D} \times$ TS 2274) $\times$ La Mé and $(\mathrm{LM} 630 \mathrm{D} \times \mathrm{TNR} 115) \times$ La Mé was $10 \%$. Vertical growth rates of the different hybrids were around $50 \mathrm{~cm} /$ year (Table 6). They were similar to the control in height. In addition, hybrid types tested showed a coefficient of $10 \%$ for this vegetative trait. The best 5 progenies' bunch number, fresh fruit bunch yield, average bunch weight and palm oil yield represented 104-to $112 \%$ of the trial control and $100-109 \%$ of the trial mean all parameters put together at maturity (6-9 years after planting). Three of the 5 best progenies share a common Angola-derived parent LM 5448 T (Table 7).

Table 6. Average growth rate of the different types of hybrids tested at 6-9 years of age

\begin{tabular}{|c|c|c|c|c|c|c|}
\hline & \multicolumn{6}{|c|}{ Types of hybrids tested } \\
\hline & \multicolumn{2}{|c|}{$($ LM 630 D $\times$ TNR 115) × La Mé $(8)$} & \multicolumn{2}{|c|}{$($ LM 630 D × TS 2274) × La Mé (7) } & \multicolumn{2}{|c|}{ TNR 115 AF $\times$ La Mé (13) } \\
\hline & Mean & $\mathrm{CV}$ & Mean & $\mathrm{CV}$ & Mean & $\mathrm{CV}$ \\
\hline Height growth rate 6-9 years & 51 & $11 \%$ & 48 & $7 \%$ & 53 & $9 \%$ \\
\hline
\end{tabular}

Note. ( ): number of hybrids' progenies; CV: coefficient of variation; *: mean expressed in $\mathrm{cm} /$ year.

Table 7. Performances of 5 best progenies in BB GP25

\begin{tabular}{lllllll}
\hline Progeny & Cross type & BN & TBW $(\mathrm{kg} /$ palm/year $)$ & ABW $(\mathrm{kg})$ & Oil (t/ha $)$ & Height $(\mathrm{m})$ \\
\hline LM 12283 & LM 5448 T × LM 5463 D & 22.7 & 233.28 & 10.40 & 7.31 & 1.92 \\
LM 12273 & LM 5467 D × LM 5448 T & 22.6 & 245.73 & 11.00 & 6.80 & 1.93 \\
LM 12293 & LM 5476 D × LM 5448 T & 22.2 & 245.15 & 11.33 & 7.78 & 1.82 \\
LM 12433 & LM 5452 D × LM 5335 P & 21.6 & 238.90 & 11.25 & 6.87 & 1.98 \\
LM 12334 & LM 5469 D × LM 5445 T & 23.0 & 248.68 & 10.95 & 6.92 & 1.98 \\
5 best progenies' mean & 22.4 & 242.35 & 10.99 & 7.14 & 1.93 \\
Trial mean & 21.7 & 234.16 & 11.00 & 6.55 & 1.90 \\
Control & 21.6 & 232.38 & 10.93 & 6.35 & 1.80 \\
\hline
\end{tabular}

Note. BN: bunch number; TBW: total bunch weight; ABW: average bunch weight.

\subsection{Resistance to Fusarium Wilt}

The average Fusarium indices recorded were less than 100 on average (Table 8). Hybrids (LM 630 D $\times$ TS 2274) $\times$ La Mé revealed the lowest index for this trait $(\mathrm{IF}=83)$.

Table 8. Average Fusarium wilt index of different types of hybrids tested

\begin{tabular}{llll}
\hline & \multicolumn{3}{l}{ Types of hybrids tested } \\
\cline { 2 - 4 } & $($ LM 630 D $\times$ TNR 115) $\times$ La Mé (8) & $($ LM 630 D $\times$ TS 2274) $\times$ La Mé (7) & TNR 115 AF $\times$ La Mé $(13)$ \\
\hline Mean Fusarium index & $97(14: 15)$ & $83(22: 10)$ & $90(20: 14)$ \\
\hline
\end{tabular}

Note. ( ): number of hybrids' progenies; (14: 15) 14 tests with FI $<100$ against 15 tests with FI $>100$. 


\section{Discussion}

\subsection{Comparison of Progenies and Value of Progeny of Angolan Origin}

Analysis of variance revealed a highly significant difference between progenies for bunch production and its components both at juvenile period (3-6 years) and at mature stage (9-10 years) as well as for height at 9 years. It also showed the absence progeny $\times$ station interaction. In the absence of progeny $\times$ station interaction. The two genetic trials were merged into one trial. Data were adjusted with reference to the trial planted in Bangun Bandar (Indonesia) whose mean values of the different parameters were relatively high. In fact, the four progenies common to two trials served as bridges and were used in the estimates of the adjustment factors. The 5 progenies that ranked first in the comparison of mean values (Table not shown) have produced 8.16 to $21 \%$ more oil than the control at 9-10 years after planting. Their oil yields were comparable to those of oil palm commercial fields planted Deli $\times$ La Mé materials of the second cycle of RRS represented by the control. However, they can be selected for improvement for future utilization as seed trees. They should be reproduced for seed supply to farmers. Four (4) progenies have recorded a lower height growth rate $(44 \mathrm{~cm} /$ year, on average) than the control at 9 years after planting-period. In fact, the period is considered that of the exponential growth phase in oil palm (Baudouin \& Jacquemard, 1987).

The second analysis of variance revealed the absence of an effect of each of the La Mé origin, Angola origin, and Angola parent. However, the 3 progenies that ranked among the 5 best in oil production per unit area had one common parent, i.e., LM $5448 \mathrm{~T}$ a descendant of (LM $630 \mathrm{D} \times \mathrm{TNR} 115)$ cross. In fact, LM $5448 \mathrm{~T}$ has demonstrated a good GCA for this trait. Therefore, it is possible to disseminate planting material derived from Angola origin with moderate height growth rate than the Deli $\times$ La Mé seeds that are currently supplied to oil palm growers. It should be considered a genetic progress on the trait since Angolan origin was characterised in the 'wild' state as high vertical growth rate material (Adon et al., 1998).

\subsection{Mean Values of Hybrids From Angola origin-Contributed Crosses}

Fresh fruit bunches production of Angola origin-derived hybrids have $130 \mathrm{~kg} /$ tree at 3-6 years of age (17 t/ha) and $190 \mathrm{~kg} /$ tree $(26 \mathrm{t} / \mathrm{ha})$ at $9-10$ years. The values are very close to the potential yield of planting materials of the second cycle of RRS currently supplied to oil palm growers by the French PalmElit considered the producer of high potential bunches and oil yields planting materials for the African oil palm climates and soils. The relatively high bunch production of the Angolan origin-contributed progenies was due to their high bunch number (23 bunches per tree at 3-6 years and 15 at $9-10$ years) of medium size $(6 \mathrm{~kg} / \mathrm{bunch}$ and $13 \mathrm{~kg} / \mathrm{bunch}$, respectively). The performances obtained were comparable to those the control LM $2 \mathrm{~T} \times \mathrm{DA} 10 \mathrm{D}$ which is one of the best crosses of the first selection cycle in bunch production. In fact, it is not common to identify Deli $\times$ La Mé seeds from the second cycle of RRS that are currently more productive than the LM $2 \mathrm{~T} \times \mathrm{DA} 10 \mathrm{D}$ control. It can be argued that the hybrids (Deli $\times$ Angola) $\times$ La Mé and Angola selfed $\times$ La Mé had a satisfactory bunch production per hectare. The performance obtained indicated the efficiency of the selection made in the accessions from Angola natural oil palm groves. Indeed, a 10\% improvement in bunch production was recorded in the second stage of evaluation of this material compared to the one obtained in the first stage (Adon, 1995).

Oil extraction rates varied from $20.8 \%$ to $21.9 \%$ for hybrids contributed by the Angolan origin. OER values were comparable to that of the control $(20.5 \%)$ which was recognised as poor performer for this trait. This characteristic of Angolan oil palm genotypes, which was already detected in the first stage of their evaluation by Adon et al. (1998), would be a consequence of a low percentage of pulp on fruit and a low oil content of the pulp. Okwagwu (1985) explained the low percentage of pulp to fruit by the presence of a large kernel. In fact, this trait is said to be governed by a gene related to the $\operatorname{sh}^{-}$(tenera) gene of the 2 ancestors TNR 115 and TS 2274 of Angolan origin.

Mean oil yields of the hybrids derived from Angola origin were around 3.5 t/ha at 3-6 years and 5.3 t/ha at 9-10 years. Yields were comparable to those of the control, which were $3.5 \mathrm{t} / \mathrm{ha}$ and $5.5 \mathrm{t} / \mathrm{ha}$, respectively, for the same periods. However, yields were relatively lower than those of the Deli $\times \mathrm{La} \mathrm{Me} \mathrm{seeds} \mathrm{supplied} \mathrm{to} \mathrm{oil} \mathrm{palm}$ growers, which are producing $15-25 \%$ more oil than the LM $2 \mathrm{~T} \times \mathrm{DA} 10 \mathrm{D}$ control. Angolan origin-based hybrids can be considered less productive in oil. However, the existence of considerable variability for this trait especially in the hybrids (LM $630 \mathrm{D} \times \mathrm{TNR} 115) \times \mathrm{La}$ Me $(\mathrm{CV}=10 \%)$ would allow the selection of progenies with a performance comparable to that of the current Deli $\times$ La Mé planting materials. They showed a vertical growth rate of about $50 \mathrm{~cm} /$ year recorded from two measures made one at 6 years and the other one at 9 years. The value was close to that of the control. Some of the progenies grew slower than the control, which was considered as a low vertical growth rate progeny (about $50 \mathrm{~cm} /$ year) in La Mé (Jacquemard \& Baudouin, 1987). This characteristic was a pitfall in using Angolan materials in the first stage of evaluation, where Angola $\times$ 
Angola progenies averaged $117 \%$ of the control (Adon, 1995). In fact, oil palm planting materials must represent at most $100 \%$ of the control in terms of plant height. There was a genetic progress in reducing the vertical growth rate.

The Fusarium index, which is an indicator of oil palm tolerance, was less than 100 showing that Angolan origin-based hybrids were tolerant to Fusarium wilt. The tolerance to Fusarium observed in the Angolan origin in the first stage of evaluation was preserved. This character is an asset for the material of Angolan origin (Durand-Gasselin et al., 2000). Thus, the Angolan source material provides a new source of tolerance to Fusarium that would eventually lead to the distribution of seeds to susceptible areas.

\subsection{Introgression of Angola Origin Genitors in Main Breeding Programme}

In the long term, there is the possibility of genetic progress with selected oil palms of Angola origin in combination with the Deli origin. It would be possible, on the one hand, to increase the genetic basis of Group A of the reciprocal recurrent selection, which until now has consisted solely of Deli dura $\left(\mathrm{sh}^{+}\right.$gene) materials, and on the other hand, to introduce there the tenera (sh'gene present in the Angola origin). In addition, intra-group A recombinations between Angolan genitors selected in this work and Indonesian genitors acquired from an oil palm materials exchange programme between the Centre National de Recherches Agronomiques (CNRA) of Côte d'Ivoire and the Indonesian Oil palm Research Institute (IOPRI) would constitute a phase of the third cycle of RRS.

A genitor of Angola origin (LM $5448 \mathrm{~T}$ ) has distinguished itself by its good general combining ability for agronomic performance, notably the tolerance to Fusarium, low vertical growth rate, and a decumbent architecture. Selected genitor deserves to be integrated as a priority in recurrent populations. There are two ways to use it. The first aims to test certain trees from LM $5448 \mathrm{~T}$ AF with partners from Group B. The production of Angola $\times$ La Mé seeds' objective is to identify better genotypes than their ancestors. The second is to integrate LM 5448 T into the Group A's populations, which will be broaden and enriched with the Angola origin.

\section{Conclusion}

The main objectives of introducing Angolan oil palm materials in Group A were, on the one hand, to enrich the genetic base of Group A for the selection scheme and, on the other hand, to introduce the $\operatorname{sh}^{-}($tenera $)$gene. The genitor of Angola origin LM $5448 \mathrm{~T}$ and the descendants from its selfing offered new genes for bunch production and tolerance to Fusarium to Group A. Recombinations involving Angola's tenera and pisifera of Deli $\times$ Angola crosses are means of transferring the sh'gene into Group A (which initially consisted only of dura $\left(\mathrm{sh}^{+}\right.$gene). Eventually, it will be possible to make crosses of the pisifera type of Group A $\times$Group B dura. This inversion of the traditional direction of crosses, i.e., Group A dura $\times$ Group B pisifera would make it possible to avoid problems of insufficient pollen on the pisifera of Group B which are rather too female. However, the low average bunch weight of Group B materials consisting of tenera and pisifera would result in the production of small bunches which leads to a reduced number of fruits per bunch. Therefore, seed producers will expect less seeds for supply to growers. Therefore, seed production should take the average bunch weight of Group B material into account.

\section{References}

Acquaah, G. (2007). Principles of plant genetics and breeding. Blackwell Publishing, Oxford.

Adon, B. (1995). Evaluation des introductions de palmier à huile (Elaeis guineensis Jacq.) Utilisation dans le schéma de sélection récurrente réciproque (Thèse de doctorat de 3ème cycle, Universite de Cocody, Côte d'Ivoire).

Adon, B., Baudouin, L., Durand-Gasselin, T., \& Kouame, B. (1998). Utilisation du matériel non amélioré pour la sélection du palmier à huile, l'origine Angola. Plantations, Recherche, Développement, 201-207

Adon, B., Kouame, B., \& Jacquemard, J. C. (1993). Characterisation of wild populations of oil palm (Elaeis guineensis Jacq.) in 4 regions of Nigeria. Genetic progress requires the identification and inventory of genes (pp. 385-398). AUPELF-UREF, John Libbey Eurotext, Paris.

Bakoumé, C. (2016). Genetic diversity, erosion and conservation in oil palm. In M. R. Ahaja \& S. Mohan Jain (Eds.), Genetic diversity and erosion in plants-Case studies (pp. 1-31). Springer International Publishing AL, Zurich. https://doi.org/10.1007/978-3-319-25954-3_1

Cao, T. T. V. (1995). Organisation de la variabilité génétique chez le palmier à huile (Elaeis guineensis Jacq). Conséquences pour l'amélioration des populations et la création variétale (Thèse de doctorat, Institut National Agronomique, France). 
Cochard, B., Noiret, J. M., Baudouin, L., Flori, A., \& Amblard, P. (1993). Second cycle of reciprocal recurrent selection in Oil Palm (Elaeis guineensis Jacq.), result of tests of hybrids Deli $\times$ La Mé. Oléagineux, 48, 441-451.

Durand-Gasselin, T., Franqueville, H., Diabaté, S., Cochard, B., Adon, B., \& Amblard, P. (2000). Assessing and utilizing sources of resistance to Fusarium Wilt in oil palm (Elaeis guineensis Jacq.) genetic resources. Proceedings of the International Symposium on Oil Palm Genetic Resources and Use (pp. U1-U25). PORIM/IPGRI, Kuala Lumpur.

Gascon, J. P., \& de Berchoux, C. (1964). Characteristics of the production (Elaeis guineensis Jacq.) of various origins and their crossbreeding: Application to the selection of oil palm. Oléagineux, 19(2), 75-84.

Gascon, J. P., Jacquemard, J. C., Houssou, M., Boutin, D., Chaillard, H., \& Kamga Fondjo, F. (1981). La production de semences sélectionnées de palmier à huile (Elaeis guineensis Jacq.). Oléagineux, 36(10), 475-486.

Hartley, C. W. S. (1980). The oil palm (Elaeis guineensis Jacq.). Scientific and Technical Publication, Longman, New-York.

Jacquemard, J. C. (1979). Contribution à l'étude de la croissance en hauteur du stipe d'Elaeis guineensis Jacq. Etude du croisement L2T × DI OD. Oléagineux, 34(11), 491-495.

Jacquemard, J. C., \& Baudouin, L. (1987). Contribution à l'étude de la croissance du palmier à huile. Présentation d'un modèle descriptif. Oléagineux, 42(10), 343-349.

Meunier, J., \& Gascon, J. P. (1972). Le schéma de sélection du palmier à huile à l'I.R.H.O. Oléagineux, 27, 1-12.

Nouy, B., Asmady, \& Baudouin, L. (1989). Progrès génétique obtenu à Aek Kwasan (Nord Sumatra) par l'exploitation des reproductions d'hybrides de palmier à huile sélectionnés. Oléagineux, 36(3), 35-143.

Okwuagwu, C. O. (1986). The genetic basis for the low correlation between dura and tenera fullsib shell to fruit ratio in the oil palm Elaeis guineensis Jacq. Proceedings of the 1987 International Oil Palm/Palm Oil Conferences-Progress and Prospects (pp. 143-154). Conference: Agriculture, Kuala Lumpur.

Ollagnier, M., Lauzerat, A., Olivin, J., \& Ochs, R. (1978). Evolution des sols sous palmeraie après défrichement de la forêt. Oléagineux, 33, 537-547.

Quencez, P. (1996). La culture du palmier à huile en Afrique Intertropicale: Les conditions du milieu physique. Oleagineux, Corps gras, Lipides, 3(2), 116-118.

Renard, J. L., Gascon, J. P., \& Bachy, A. (1972). Recherches sur la fusariose du palmier à huile. Oléagineux, $27(12), 581-591$.

Rosenquist, E. A. (1990). An overview of breeding technology and selection in Elaeis guineensis. Proceedings of 1989 International Palm Oil Congress-Agriculture, Kuala Lumpur (pp. 5-25).

Tampubolon, F. H., Daniel, C., \& Ochs, R. (1990). Réponses du palmier à huile aux fumures azotées et phosphorées à Sumatra. Oléagineux, 45(11), 475-486.

\section{Abbreviations}

AN 2 T: Second genitor of tenera type and of Angolan origin selected at La Mé; BB: Bangun Bandar (Indonesia); D: Dura palm; DA 10 D: 10th genitor of dura type selected at Dabou; LM: La Mé (Côte d'Ivoire); T: tenera palm; P: pisifera palm.

\section{Copyrights}

Copyright for this article is retained by the author(s), with first publication rights granted to the journal.

This is an open-access article distributed under the terms and conditions of the Creative Commons Attribution license (http://creativecommons.org/licenses/by/4.0/). 